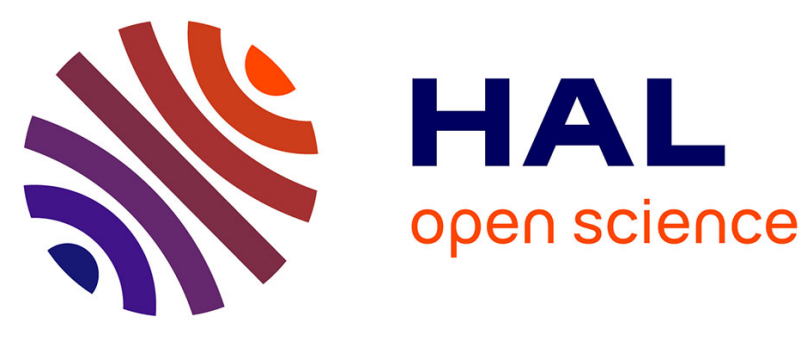

\title{
Designing Boron and Metal Complexes to Fluoride Recognition: Computational Perspective
}

Renato Pereira Orenha, Letícia Bermudes Peixoto, Giovanni Finoto Caramori, Maurício Jeomar Piotrowski, Krys Elly de Araújo Batista, Julia Contreras-Garcia, Carlos Cardenas, Nelson Henrique Morgon, Fernando Mendizabal, Renato Luis Tame Parreira

\section{To cite this version:}

Renato Pereira Orenha, Letícia Bermudes Peixoto, Giovanni Finoto Caramori, Maurício Jeomar Piotrowski, Krys Elly de Araújo Batista, et al.. Designing Boron and Metal Complexes to Fluoride Recognition: Computational Perspective. Physical Chemistry Chemical Physics, 2021, 10.1039/x0xx00000x . hal-03371960

\section{HAL Id: hal-03371960 https://hal.science/hal-03371960}

Submitted on 9 Oct 2021

HAL is a multi-disciplinary open access archive for the deposit and dissemination of scientific research documents, whether they are published or not. The documents may come from teaching and research institutions in France or abroad, or from public or private research centers.
L'archive ouverte pluridisciplinaire HAL, est destinée au dépôt et à la diffusion de documents scientifiques de niveau recherche, publiés ou non, émanant des établissements d'enseignement et de recherche français ou étrangers, des laboratoires publics ou privés. 


\title{
Designing Boron and Metal Complexes to Fluoride Recognition: Computational Perspective
}

Received 00th January 20xx, Accepted 00th January 20xx DOI: $10.1039 / x 0 x \times 00000 x$

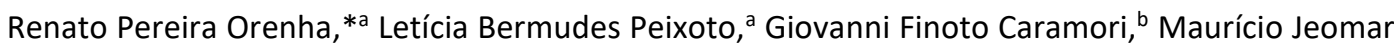
Piotrowski, ${ }^{c}$ Krys Elly de Araújo Batista, ${ }^{c}$ Julia Contreras-Garcia, ${ }^{d}$ Carlos Cardenas, ${ }^{\text {e, }}{ }^{,}$Nelson H. Morgon, ${ }^{\mathrm{g}}$ Fernando Mendizabal, ${ }^{\mathrm{h}}$ and Renato Luis Tame Parreira ${ }^{\mathrm{a}}$

\begin{abstract}
The fluoride anion $\left(\mathrm{F}^{-}\right)$may have beneficial or harmful effects on the environment depending on its concentration. Here, we shed light into the $\mathrm{F}^{-}$recognition by compounds containing boron, tellurium and antimony, which experimentally demonstrated to be capable of interacting with the ion $\mathrm{F}^{-}$in a partially aqueous medium. The boron and metal complexes recognize the anion $\mathrm{F}^{-}$from an electrostatic principally energy, but with an importantly contribution of the orbital interactions energy. Since that the natural orbitals for chemical valence (NOCV) methodology indicates that the main orbital interactions behind the fluoride recognition are $\sigma$ bonds between the receptors and the anion $\mathrm{F}^{-}$. The charged receptors, which provide: i) two $\mathrm{B}$ atoms; ii) one $\mathrm{B}$ atom and one $\mathrm{Sb}$ atom; and iii) one $\mathrm{B}$ atom and one Te atom, to directly interact with the ion $\mathrm{F}^{-}$appear as one of the best structures to anionic recognition of $\mathrm{F}^{-}$. It is supported by combination of favorable electrostatic and $\sigma$ bond interactions. Overall, the presence of electron donor groups, such as, $-\mathrm{CH}_{3}$ and $-\mathrm{OH}$, in the receptors structure destabilizes the fluoride recognition because decrease the attractive electrostatic energy and increase the Pauli repulsion energy in the receptor $\cdots \mathrm{F}^{-}$bonds. Notably, electron acceptor groups as, for example, $-\mathrm{CN}$ and $-\mathrm{NO}_{2}$ in the receptors structure favor the interaction with the ion $\mathrm{F}^{-}$, due to improving of the electrostatic and $\sigma$ bond interactions. This study opens the gates to find the main features of a receptor able to $\mathrm{F}^{-}$recognition.
\end{abstract}

\section{Introduction}

Anion recognition is an interesting research field due to the importance of these molecules to the environmental and biological processes. ${ }^{1}$ Compounds that can specifically bind to anions in aqueous milieu are of substantial relevance. The comprehension of the bonding situation between an anion and its receptor is crucial to the rational design of new receptors with improved properties. ${ }^{2-4}$ The fluoride anion is usually involved in the management of osteoporosis. This ion is also added to the water supply and toothpaste aiming to promote

a. Núcleo de Pesquisas em Ciências Exatas e Tecnológicas, Universidade de Franca, Franca, SP, 14404-600, Brazil. E-mail: rpo9@hotmail.com / renato.parreira@unifran.edu.br

b. Departamento de Química, Universidade Federal de Santa Catarina, Campus Universitário Trindade, CP 476, Florianópolis, SC, 88040-900, Brazil.

Department of Physics, Federal University of Pelotas, PO Box 354, 96010-900, Pelotas, RS, Brazil.

d. Sorbonne Université, CNRS, Laboratoire de Chimie Théorique, LCT, F. 75005 Paris, France.

e. Departamento de Física, Facultad de Ciencias, Universidad de Chile, Casilla 653, 7800024, Santiago, Chile.

f. Centro para el Desarrollo de la Nanociencia y la Nanotecnología (CEDENNA), Avda Ecuador 3493, Santiago 9170124, Chile.

g. Instituto de Química, Universidade Estadual de Campinas, CP 6154, 13083-970, Campinas, SP, Brazil.

h. Departamento de Química, Facultad de Ciencias, Universidad de Chile, Casilla 654, Santiago, Chile.E-mail: hagua@uchile.cl

Electronic Supplementary Information (ESI) available: Cartesian coordinates of the optimized geometries, and NOCV and QTAIM results to selected structures. See DOI: 10.1039/x0xx00000x positive results to dental health. ${ }^{5}$ Nevertheless, the presence of this ion in high level is associated with skeletal and dental fluorosis. ${ }^{6}$ Therefore, it is necessary to create new methodologies to $\mathrm{F}^{-}$identify in aqueous media. The maximum contaminant level of the fluoride ion in drinking water was set at $4 \mathrm{ppm}$ by the Environmental Protection Agency (EPA). ${ }^{7}$ The most important goal would be developing a technique capable to detecting the ion $\mathrm{F}^{-}$below of this limit.

The challenge of to elaborate structures, soluble in water, with an affinity sufficiently high to $\mathrm{F}^{-}$is immense because of the expressive hydration enthalpy of this ion. ${ }^{8}$ Lewis acids containing elements of the main group have shown excellent results in the recognition of small ions. ${ }^{9}$ Alternative fluoride receptors based on transition metals or lanthanides complexes have also been investigated in the literature. ${ }^{10-14}$ The synthesis of boron-based compounds was an achievement, as it generated water-soluble structures capable of identifying fluoride anions. ${ }^{15,16}$ To ensure that these boron molecules can efficiently interact with fluorine anions, some strategies were proposed. The addition of electron-withdrawing ligands to boron-containing molecules is one of the concepts adopted to increase the Lewis acidity these boron compounds. ${ }^{17}$ Another idea is related to the oxidation of the boron structures, such as, in $\mathrm{Fc}-\mathrm{B}(\mathrm{OH})_{2} \rightarrow\left[\mathrm{Fc}-\mathrm{B}(\mathrm{OH})_{2}\right]^{+}+\mathrm{e}^{-}(\mathrm{Fc}=$ ferrocenyl), in which the oxidized species show an accretion of Lewis acidity compared to non-oxidized ones, leading to a significant increase in the affinity of fluoride for boron. ${ }^{18}$ Boron-based bidentate Lewis acids can also be used to chelate anionic guests. The anion 
affinity can be controlled from the onium main-group element nature. ${ }^{19}$

Strong Lewis acids also can be obtained from group 15 elements, chiefly antimony. ${ }^{20}$ The use of organic ligands in antimony $(\mathrm{V})$ complexes creates strong Lewis acids, but that not show corrosive properties, such as, in pentahalide analogous. ${ }^{21}$ Solutions with high water content $\left(>50 \% \mathrm{H}_{2} \mathrm{O}\right)$ promote critical problems to fluoride recognition from antimony structures. It occurs due to the preferential $\mathrm{H}_{2} \mathrm{O}$ coordination to antimony complexes vacancy. ${ }^{22}$ Organostiboranes and tetraarylstibonium ions are Lewis acids that can bind $\mathrm{F}^{-}$in aqueous solution. ${ }^{9,23}$ Also, antimony compounds can be associated with one transition-metal center aiming for an easily detectable optical sign to $\mathrm{F}^{-}$recognition. ${ }^{9}$ Recently, neutral bidentate antimony $(\mathrm{V})$ compound was synthesized. This molecule represented the first neutral main group Lewis acid that is capable to detect the anion $\mathrm{F}^{-}$in water media. ${ }^{24}$

To elucidate the nature behind of the fluoride recognition in aqueous environment, the bonding between $\mathrm{F}^{-}$and selected boron, tellurium and antimony structures, experimentally recognized as efficient fluoride receptors, will be initially evaluated (Scheme 1).4,9,23,25-27 Importantly, the molecules with the highlighted skill to interact with the anion $\mathrm{F}^{-}$will be modified using electron donor or acceptor groups, such as, $-\mathrm{OH},-\mathrm{CH}_{3},-$ $\mathrm{CN}$ and $-\mathrm{NO}_{2}$ to project complexes with larger capability to recognize the ion $\mathrm{F}^{-}$(Scheme 2). The bond nature will be investigated from the EDA-NOCV methodology. In addition, the topological analysis of the electron density will be realized using the quantum theory of atoms in molecules (QTAIM) method.

\section{Computational Methods}

The geometry of all studied compounds was optimized without restraints, and the vibrational frequencies were calculated from the BP8628,29-D3(BJ) ${ }^{30-34}$ method and def2-TZVP basis set. ${ }^{35}$ The water solvation was considered from the polarizable continuum model (PCM) using the integral equation formalism variant (IEFPCM). ${ }^{36}$ Vibrational analyses for all optimized geometries validate that they are all energy minima at the level of theory applied here. The wavefunction (for QTAIM analysis) was obtained from the BP86-D3(BJ)/def2-TZVP+PCM $\left(\mathrm{H}_{2} \mathrm{O}\right)$ computational model. The desolvation energy $\left(\Delta E_{\text {des }}\right)$ was calculated using the BP86/def2-TZVP+PCM $\left(\mathrm{H}_{2} \mathrm{O}\right)$ theory level. $\Delta E_{\text {des }}$ is equal to $\Delta E_{\text {des,complex }}-\Delta E_{\text {des,receptor }}-\Delta E_{\text {des,anion, whe the }}$

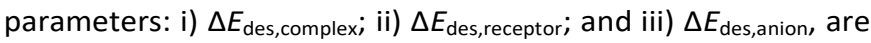
the interaction energy between the polarized solute: i) receptor $\cdots \mathrm{F}^{-}$; ii) receptor; and iii) anion $\mathrm{F}^{-}$, and the solvent $\mathrm{H}_{2} \mathrm{O}$, respectively. The precision of the integration grid was sets to UltraFine, $(99,590)$ grid, to these calculations. ${ }^{37}$ Here, the calculations were performed using the Gaussian 16 Revision A.03 software. ${ }^{38}$ The topological analysis of the electron density (from the QTAIM ${ }^{39,40}$ method) was calculated using the AIMAll (Version 17.01.25) software. ${ }^{41}$

The binding analysis was realized from the EDA ${ }^{42}$ method in combination with the NOCV 43,44 methodology. According to the EDA formalism, the interaction energy, $\Delta E_{\text {int }}$, between, for example, the receptor 1 and the anion $\mathrm{F}^{-}$can be decomposed into electrostatic, $\Delta V_{\text {elstat, }}$ Pauli repulsion, $\Delta E_{\text {Pauli, }}$ and orbital interactions, $\Delta E_{\mathrm{oi}}$, components. ${ }^{42}$ The term $\Delta V_{\text {elstat }}$ represents the quasi-classical electrostatic interaction between unperturbed charge densities and nuclei of the geometrically deformed fragments. The Pauli repulsion $\Delta E_{\text {Pauli }}$ contains the destabilizing interactions between the occupied orbitals and is accountable for the steric repulsion. The orbital interactions energy $\Delta E_{\mathrm{oi}}$ reflects the charge transfer (donor-acceptor interactions between occupied orbitals in one fragment with the empty orbitals of another fragment) and polarization (unoccupied/occupied orbital mixing in one moiety due to the presence of the other). Besides, the $\Delta E_{\text {des }}$ parameter will be summed to $\Delta E_{\text {int }}$ energy, $\Delta E_{\text {int+des, }}$, to evaluate the influence of the solvent environment on the interaction energy. ${ }^{45,46}$ The $\Delta E_{\text {des }}$ energy considers the electrostatic interactions associated

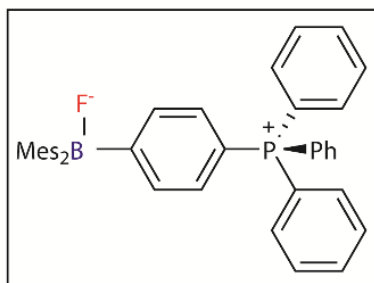

$1 \cdots \mathrm{F}^{-}$

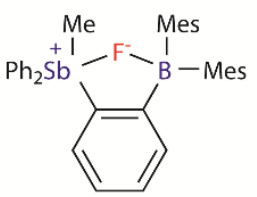

$6 \cdots \cdot \mathrm{F}^{-}$<smiles>C[15NH]c1cccc2cccc(CN)c12</smiles>

$2 \cdots \mathrm{F}^{-}$

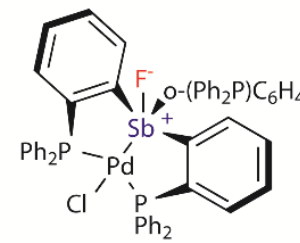

$7 \cdots F^{-}$

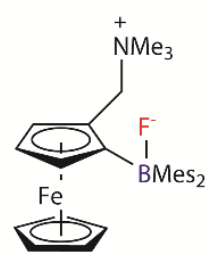

$3 \cdots \mathrm{F}$

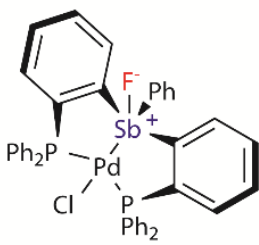

$8 \cdots \mathrm{F}$<smiles>C[As+](F)(F)c1cccc2cccc([Te](C)(C)c3ccccc3)c12</smiles>

$4 \cdots \mathrm{F}^{-}$

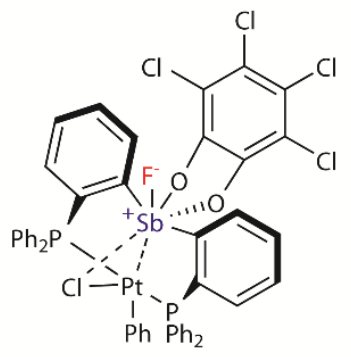

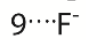

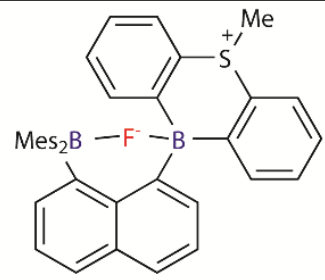

$5 \cdots \cdot \mathrm{F}$

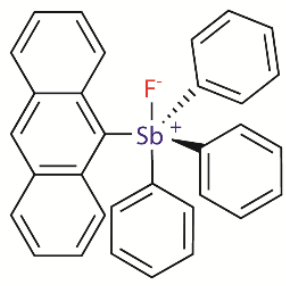

$10 \cdots \mathrm{F}^{-}$

Scheme 1. Selected boron, tellurium and antimony structures to $\mathrm{F}^{-}$recognition: (1-10) $\cdots \mathrm{F}^{-}$. 


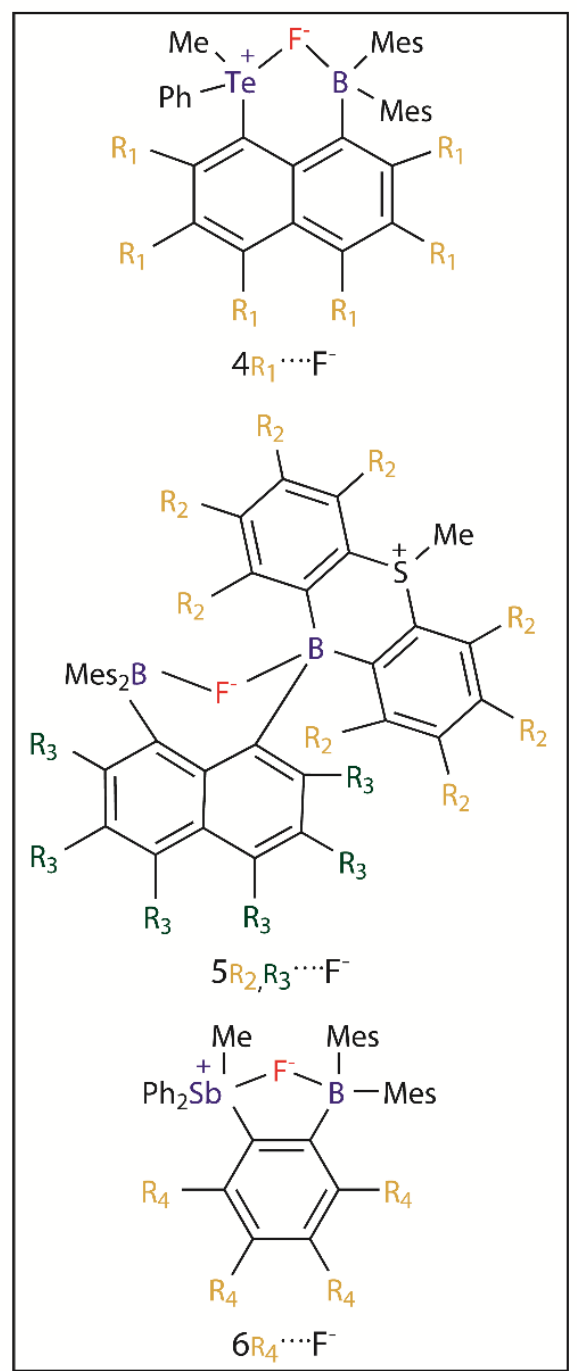

Scheme 2. Structures designed from the complexes $(4-6) \ldots \mathrm{F}^{-}: 4 \mathrm{CH}_{3} \cdots \mathrm{F}^{-}\left(\mathrm{R}_{1}=\mathrm{CH}_{3}\right)$

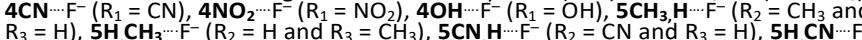

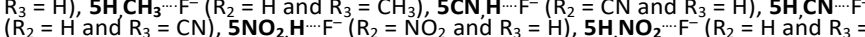

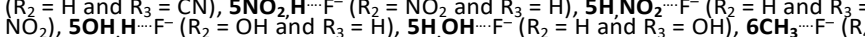
$\left.=\mathrm{CH}_{3}\right), 6 \mathrm{CN} \cdots \mathrm{F}^{-}\left(\mathrm{R}_{4}=\mathrm{CN}\right), 6 \mathrm{NO}_{2} \cdots \mathrm{F}^{-}\left(\mathrm{R}_{4}=\mathrm{NO}_{2}\right)$ and $6 \mathrm{OH}^{\prime \cdots} \mathrm{F}^{-}\left(\mathrm{R}_{4}=\mathrm{OH}\right)$.

to desolvation penalty. As will be shown by EDA analysis, it represents a relevant approach due to predominantly contribution of the $\Delta V_{\text {elstat }}$ term to $\Delta E_{\text {int }}$ energy. In the NOCV methodology, the total deformation density $(\rho)$ of $\Delta E_{\mathrm{oi}}$ is decomposed into deformation density flow channels $\left(\Delta \rho_{\mathrm{i}}\right)$. Each $\Delta \rho_{\mathrm{i}}$ is also related the energy $\left(\Delta E_{\mathrm{o} i, \mathrm{i}}\right)$ and their charge transfer $\left(\Delta q_{\mathrm{i}}\right) .^{43,44}$ The EDA-NOCV results were obtained through of the BP86 method along with the QZ4P basis set. ${ }^{47}$ This basis set is recommended for small anionic species such as $F^{-} .48$ Scalar relativistic corrections were included self-consistently from the zero-order regular approximation (ZORA). ${ }^{49}$ The accuracy of the integration grid (Becke grid) was, for these calculations, sets to
VERYGOOD. ${ }^{50}$ The EDA-NOCV calculations were done in gas phase from the ADF2020 software. ${ }^{51-53}$

\section{Results and Discussion}

\subsection{Recognition of the Fluoride Anion using Experimentally Developed Receptors}

Initially, the optimized geometry of the complexes $(\mathbf{2}, \mathbf{4}$, and $\mathbf{6}-$ 10).... $F^{-}$show RMSd values $(0.292 ; 0.234 ; 0.244 ; 0.660 ; 0.443$; 0.364 and $0.293 \AA$, respectively) lower than $1.000 \AA$ in relation to geometry of these complexes obtained from the $X$-ray data. ${ }^{2,9,23,27}$ It attests the accuracy of the computational model, BP86-D3(BJ)/def2-TZVP, chosen to optimize the geometry of the complexes investigated (Table S1).

Selected bond lengths in the complexes (1-10) $\cdots \mathrm{F}^{-}$are organized in the Table 1 to a first analysis of the skill of the receptors 1-10 to recognize the anion $\mathrm{F}^{-}$. The values of the bond length $r\left(B \cdots F^{-}\right)$are lower than $r\left(T e \cdots F^{-}\right)$and $r\left(S b \cdots F^{-}\right)$. Besides, the value of the bond length $r\left(\mathrm{Te}_{\cdots} \cdots \mathrm{F}^{-}\right)$is larger compared to $\mathrm{r}\left(\mathrm{Sb} \cdots \mathrm{F}^{-}\right)$. These data indicate the boron compounds as preferential receptor structures to recognize the anion $\mathrm{F}^{-}$. Importantly, the values of the bond length $r\left(B \cdots \mathrm{F}^{-}\right)$in the

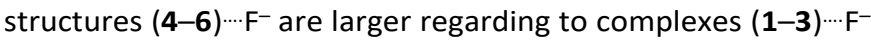
. However, in the molecules 4-6, there is another $\mathrm{B}, \mathrm{Te}$ or $\mathrm{Sb}$ atom closer to anion $\mathrm{F}^{-}$. As will be shown from EDA analysis, this chemical environment provides to compounds 4-6 a preferentially interaction energy with the anion $\mathrm{F}^{-}$concerning to receptors 1-3.

To elucidate the recognition of the fluoride ion, the interaction between the receptors $\mathbf{1 - 1 0}$ and the fluoride anion was studied from the EDA method. There are attractive $\Delta E_{\text {int }}$ values between the compounds $\mathbf{1 - 1 0}$ and the anion $\mathrm{F}^{-}$(Table 2 ). These favorable values of $\Delta E_{\text {int }}$ can be explained because the sum of the attractive energetic terms ( $\Delta V_{\text {elstat }}$ and $\left.\Delta E_{\mathrm{oi}}\right)$ overcomes the $\Delta E_{\text {pauli }}$ repulsive energy. Pertinently, the term $\Delta V_{\text {elstat }}$ appears as the most important attractive energetic term ( $\Delta V_{\text {elstat }}$ represents $56-66 \%$ of the sum $\left.\Delta V_{\text {elstat }}+\Delta E_{\mathrm{oi}}\right)$ for the interactions (1-10) $\cdots \mathrm{F}^{-}$. However, there is also a relevant contribution of the component $\Delta E_{\mathrm{oi}}(34-44 \%)$ to energy $\Delta V_{\text {elstat }}$ $+\Delta E_{\mathrm{oi}}$. The receptors $\mathbf{8}$ and $\mathbf{1 0}$ interact with the anion $\mathrm{F}^{-}$with the largest contribution of the $\Delta V_{\text {elstat }}$ term (66\%) to energy $\Delta V_{\text {elstat }}+\Delta E_{\text {oi }}$. On the other hand, the structure 1 interacts with the anion $\mathrm{F}^{-}$with the largest weight of the $\Delta E_{\mathrm{oi}}$ component (44 $\%)$ to energy $\Delta V_{\text {elstat }}+\Delta E_{\text {oi }}$.

The receptors that interact with the anion $\mathrm{F}^{-}$from a most attractive way $\left(\Delta E_{\text {int }}=-164.77,-173.23\right.$ and $-166.47 \mathrm{kcal} \mathrm{mol}^{-1}$ to complexes $4 \cdots \mathrm{F}^{-}, \mathbf{5} \cdots \mathrm{F}^{-}$and $\mathbf{6} \cdots \mathrm{F}^{-}$, respectively) are the ones that provide to two atoms for a direct interaction with the anion $\mathrm{F}^{-}$(Scheme 1). The structure $\mathbf{5}$, where two $\mathrm{B}$ atoms are available 
Table 1. The main bond distances ( $r$ / $\AA$ ) between the $B, T e$ and $\mathrm{Sb}$ atoms of the: $i$ receptors 1-10; and ii) derivatives structures, and the anion $\mathrm{F}^{-}$.

\begin{tabular}{|c|c|c|c|c|}
\hline Complex & $r\left(B \cdots F^{-}\right)$ & $r\left(B \cdots F^{-}\right)$ & $\mathrm{r}\left(\mathrm{Te}^{\left.\mathrm{N} \cdots \mathrm{F}^{-}\right)}\right.$ & $r\left(S b \cdots F^{-}\right)$ \\
\hline $1 \cdots F^{-}$ & 1.489 & - & - & - \\
\hline $2 \cdots F^{-}$ & 1.505 & - & - & - \\
\hline $3 \cdots \mathrm{F}^{-}$ & 1.491 & - & - & - \\
\hline $4 \cdots F^{-}$ & 1.541 & - & 2.519 & - \\
\hline $4 \mathrm{CH}_{3} \cdots \mathrm{F}^{-}$ & 1.532 & - & 2.550 & - \\
\hline $40 \mathrm{H}^{\cdots \cdot \mathrm{F}^{-}}$ & 1.530 & - & 2.528 & - \\
\hline $4 \mathrm{NO}_{2} \cdots \mathrm{F}^{-}$ & 1.508 & - & 2.646 & - \\
\hline $4 \mathrm{CN} \cdots \mathrm{F}^{-}$ & 1.514 & - & 2.665 & - \\
\hline $5 \cdots \mathrm{F}^{-}$ & $1.703^{[a]}$ & $1.561^{[b]}$ & - & - \\
\hline $5 \mathrm{CH}_{3}, \mathrm{H}^{\cdots \cdots \mathrm{F}^{-}}$ & $1.676^{[a]}$ & $1.565^{[b]}$ & - & - \\
\hline $5 \mathrm{H}, \mathrm{CH}_{3} \cdots \mathrm{F}^{-}$ & $1.694^{[a]}$ & $1.548^{[b]}$ & - & - \\
\hline $5 \mathrm{OH}, \mathrm{H}^{\cdots} \cdot \mathrm{F}^{-}$ & $1.632^{[a]}$ & $1.603^{[b]}$ & - & - \\
\hline $5 \mathrm{H}, \mathrm{OH} \cdots \mathrm{F}^{-}$ & $1.713^{[a]}$ & $1.542^{[b]}$ & - & - \\
\hline $5 \mathrm{NO}_{2}, \mathrm{H} \cdots \mathrm{F}^{-}$ & $2.105^{[a]}$ & $1.452^{[b]}$ & - & - \\
\hline $5 \mathrm{H}, \mathrm{NO}_{2} \cdots \cdot \mathrm{F}^{-}$ & $1.631^{[a]}$ & $1.561^{[b]}$ & - & - \\
\hline $5 \mathrm{CN}, \mathrm{H}^{\prime} \cdots \mathrm{F}^{-}$ & $1.971^{[a]}$ & $1.472^{[b]}$ & - & - \\
\hline $5 \mathrm{H}, \mathrm{CN} \cdots \mathrm{F}^{-}$ & $1.668^{[a]}$ & $1.539^{[b]}$ & - & - \\
\hline $6 \cdots \mathrm{F}^{-}$ & 1.539 & - & - & 2.456 \\
\hline $6 \mathrm{CH}_{3} \cdots \mathrm{F}^{-}$ & 1.557 & - & - & 2.423 \\
\hline $60 \mathrm{H}^{\cdots \cdot \mathrm{F}^{-}}$ & 1.524 & - & - & 2.459 \\
\hline $6 \mathrm{NO}_{2} \cdots \mathrm{F}^{-}$ & 1.535 & - & - & 2.413 \\
\hline $6 \mathrm{CN} \cdots \mathrm{F}^{-}$ & 1.532 & - & - & 2.436 \\
\hline $7 \cdots \mathrm{F}^{-}$ & - & - & - & 2.066 \\
\hline $8 \cdots \mathrm{F}^{-}$ & - & - & - & 2.084 \\
\hline $9 \cdots \mathrm{F}^{-}$ & - & - & - & 2.012 \\
\hline $10 \cdots \mathrm{F}^{-}$ & - & - & - & 2.093 \\
\hline
\end{tabular}

[a] Bond length related to boron atom localized in the left position in the respective structure of the Schemes 1 and 2; and [b] Bond length related to boron atom localized in the right position in the respective structure of the Schemes 1 and 2.

to directly interact with the anion $\mathrm{F}^{-}$, appears as the best compound to recognize the anion $\mathrm{F}^{-}$. The complex $5 \cdots \mathrm{F}^{-}$shows a more favorable $\Delta E_{\text {int }}$ energy than the compounds $4 \cdots \mathrm{F}^{-}$(with one $B$ atom and one Te atom available to directly interact with the anion $\mathrm{F}^{-}$) and $6 \cdots \mathrm{F}^{-}$(with one $\mathrm{B}$ atom and one $\mathrm{Sb}$ atom available to directly interact with the anion $\mathrm{F}^{-}$) due the more attractive values of the $\Delta V_{\text {elstat }}$ and $\Delta E_{\text {oi }}$ components, despite of the more repulsive value of the $\Delta E_{\text {Pauli }}$ energy in the $5 \cdots \cdot \mathrm{F}^{-}$bond regarding to $4 \cdots \mathrm{F}^{-}$and $6 \cdots \mathrm{F}^{-}$interactions. Interestingly, the receptors $\mathbf{4}$ and $\mathbf{6}$ interact with the anion $\mathrm{F}^{-}$from a little more attractive $\Delta E_{\text {int }}$ energy than in the bond $3 \cdots \mathrm{F}^{-}$. It occurs because the more favorable $\Delta E_{\mathrm{oi}}$ term and, mainly, due to more attractive $\Delta V_{\text {elstat }}$ energetic component, despite of the more repulsive $\Delta E_{\text {pauli }}$ energy in the $4 \cdots \mathrm{F}^{-}$and $6 \cdots \mathrm{F}^{-}$interactions concerning to $3 \cdots \mathrm{F}^{-}$bond. Importantly, as will be shown in the next paragraphs, the NOCV analysis specifies that the $\mathrm{Te}^{\cdots} \cdot \mathrm{F}^{-}$and $\mathrm{Sb} \cdots \mathrm{F}^{-} \sigma$ interactions show a relevant role concerning to preferential $4 \cdots \mathrm{F}^{-}$and $\mathbf{6} \cdots \mathrm{F}^{-}$interactions regarding to $\mathbf{3} \cdots \mathrm{F}^{-}$bond. These results agree with experimental data, which indicate that the anion affinity of the boranes can be markedly enhanced, narrowing the distance between the $\mathrm{B} \cdots \mathrm{F}^{-}$binding site and the onium ion. ${ }^{2}$

In relation to structures where the ion $\mathrm{F}^{-}$directly interact with the boron atom, $(\mathbf{1}-\mathbf{3}) \cdots \mathrm{F}^{-}$, the $\mathbf{3} \cdots \mathrm{F}^{-}$interaction shows a more favorable value of the $\Delta E_{\text {int }}$ energy than in the $2 \cdots \mathrm{F}^{-}$bond and, mainly, in the $1 \cdots \mathrm{F}^{-}$bond $(-162.04,-158.62$ and -148.23 $\mathrm{kcal} \mathrm{mol}^{-1}$, respectively). Here, there are two different trends. Firstly, the most favorable $3 \cdots \mathrm{F}^{-}$bond is supported by the less repulsive $\Delta E_{\text {pauli }}$ energy, despite of the less favorable $\Delta V_{\text {elstat }}$ and $\Delta E_{\text {oi }}$ energies in the $3 \cdots \mathrm{F}^{-}$interaction in relation to $2 \cdots \mathrm{F}^{-}$bond. Secondly, the more attractive $3 \cdots \mathrm{F}^{-}$interaction is maintained by a more favorable value of the $\Delta V_{\text {elstat }}$ energetic term, despite of the more repulsive $\Delta E_{\text {pauli }}$ energy in the $3 \cdots \mathrm{F}^{-}$bond regarding to $1 \cdots \mathrm{F}^{-}$interaction.

Concerning to compounds where the antimony atom directly interacts with the anion $\mathrm{F}^{-}$, the $9 \cdots \mathrm{F}^{-}$bond shows a more attractive $\Delta E_{\text {int }}$ energy compared to $7 \cdots \mathrm{F}^{-}, \mathbf{8} \cdots \mathrm{F}^{-}$and $\mathbf{1 0} \cdots \mathrm{F}^{-}$bonds (Table 2). This result is associated with the fact of the complex $9 \cdots \mathrm{F}^{-}$has a more favorable value of the $\Delta E_{\text {oi }}$ energy in relation to compounds $7 \cdots \mathrm{F}^{-}, \mathbf{8} \cdots \mathrm{F}^{-}$and $10 \cdots \mathrm{F}^{-}$. This energy counterbalances the more repulsive value of the $\Delta E_{\text {Pauli }}$ energy in the $9 \cdots \mathrm{F}^{-}$bond in relation to $7 \cdots \mathrm{F}^{-}, \mathbf{8} \cdots \mathrm{F}^{-}$and $\mathbf{1 0} \cdots \mathrm{F}^{-}$interactions. In addition, the $9 \cdots \mathrm{F}^{-}$interaction shows a more attractive $\Delta V_{\text {elstat }}$ energy than in the $8 \cdots \mathrm{F}^{-}$and $\mathbf{1 0} \cdots \mathrm{F}^{-}$bonds. Importantly, these weak interactions between the antimony-based receptors and the anion $\mathrm{F}^{-}$can not be sufficient to overcomes the water molecules shell around this ion in a predominantly aqueous medium.

The NOCV methodology has been used to provide information about the orbital interactions associated with the $\mathrm{F}^{-}$recognition. The most relevant density deformation isosurfaces to complexes (1-10) $\cdots \mathrm{F}^{-}$are shown in the Figures 1 and 2 . Relevantly, these figures show that the $F^{-}$recognition is supported by $\sigma$-bond interactions between the receptors 1-10 and the anion $\mathrm{F}^{-}$. The structures with the most stabilizing $\Delta E_{\mathrm{oi}}$

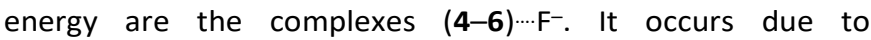
combination of the two main $\Delta E_{\mathrm{oi}, 1}$ and $\Delta E_{\mathrm{oi}, 2}$ orbital interactions energies (Table 2). For (4-6)... $\mathrm{F}^{-}$, the combination of the two most important deformation density flow channels also show the most significant charge transfer values $\left(\Delta q_{1+2}=1.028,1.220\right.$ and 1.026 a.u., respectively). Thus, the NOCV results of the

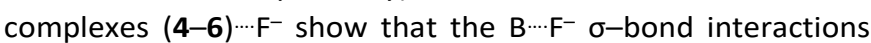
are more favorable regarding to $\mathrm{Te}^{-\cdots} \mathrm{F}^{-}$and $\mathrm{Sb} \cdots \mathrm{F}^{-} \sigma$-bonds. However, the $\mathrm{Te} \cdots \mathrm{F}^{-}$and $\mathrm{Sb} \cdots \mathrm{F}^{-} \sigma$-interactions also appear as an important factor to a more favorable recognition of the anion $\mathrm{F}^{-}$. For the other boron compounds, $(\mathbf{1}-\mathbf{3}) \cdots \mathrm{F}^{-}$, the $\sigma$-bond interaction in the $\mathbf{1} \cdots \mathrm{F}^{-}$complex is more favorable than in the (2 and 3$) \cdots \mathrm{F}^{-}$interactions. Besides, the $\sigma$-bond interactions in the (2 and 3) $\cdots \mathrm{F}^{-}$complexes appear with similar strength. The antimony-based structures (7-10) show the less attractive values of the $\Delta E_{\mathrm{oi}, 1}$ parameter $(-68.29,-64.88,-71.64$ and $59.84 \mathrm{kcal} \mathrm{mol}^{-1}$, respectively).

Additionally, the desolvation energy, $\Delta E_{\text {des }}$, of the complexes 


\section{ARTICLE}

Table 2. Analysis of the chemical bonds between the: i) receptors 1-10; and ii) designed receptors from the compounds $4-\mathbf{6}$, and the anion $\mathrm{F}^{-}$. The units of energy and charge are kcal mol-1 and a.u, respectively. ${ }^{[a, b]}$

\begin{tabular}{|c|c|c|c|c|c|c|c|c|c|c|}
\hline Complex & $\Delta E_{\text {intrdes }}$ & $\Delta E_{\text {des }}$ & $\Delta E_{\text {int }}$ & $\Delta V_{\text {elstat }}$ & $\Delta E_{\text {pauli }}$ & $\Delta E_{\text {oi }}$ & $\Delta E_{\mathrm{oi}, 1}$ & $\Delta E_{\mathrm{oi}, 2}$ & $\Delta q_{\mathrm{oi}, 1}$ & $\Delta q_{\mathrm{o}, 2}$ \\
\hline $1 \cdots F^{-}$ & -53.36 & 94.87 & -148.23 & -188.60 & 190.62 & -150.25 & -95.72 & - & 0.695 & - \\
\hline $2 \cdots F^{-}$ & -44.79 & 113.83 & -158.62 & -226.51 & 219.53 & -151.65 & -93.45 & - & 0.676 & - \\
\hline $3 \cdots \mathrm{F}^{-}$ & -49.14 & 112.90 & -162.04 & -218.02 & 205.53 & -149.56 & -93.13 & - & 0.674 & - \\
\hline $4 \cdots \mathrm{F}^{-}$ & -49.74 & 115.03 & -164.77 & -233.58 & 220.85 & -152.03 & -86.23 & -26.87 & 0.664 & 0.364 \\
\hline $4 \mathrm{CH}_{3} \cdots \mathrm{F}^{-}$ & -47.43 & 110.94 & -158.37 & -230.48 & 230.28 & -158.17 & -90.36 & -25.09 & 0.671 & 0.358 \\
\hline $40 \mathrm{H}^{\prime} \mathrm{F}^{-}$ & -52.70 & 116.08 & -168.78 & -237.27 & 225.41 & -156.91 & -90.19 & -26.25 & 0.675 & 0.363 \\
\hline $4 \mathrm{NO}_{2} \cdots \mathrm{F}^{-}$ & -58.80 & 124.74 & -183.54 & -261.07 & 244.69 & -167.16 & -99.03 & -21.53 & 0.726 & 0.328 \\
\hline $4 \mathrm{CN} \cdots \mathrm{F}^{-}$ & -57.15 & 128.88 & -186.03 & -257.22 & 233.49 & -162.30 & -96.22 & -20.71 & 0.706 & 0.321 \\
\hline $5 \cdots \mathrm{F}^{-}$ & -61.67 & 111.57 & -173.24 & -281.50 & 301.81 & -193.56 & -82.53 & -68.03 & -150.56 & 0.708 \\
\hline $5 \mathrm{CH}_{3}, \mathrm{H} \cdots \mathrm{F}^{-}$ & -59.37 & 109.12 & -168.49 & -276.53 & 305.37 & -197.33 & -81.37 & -71.05 & 0.686 & 0.525 \\
\hline $5 \mathrm{H}, \mathrm{CH}_{3} \cdots \mathrm{F}^{-}$ & -57.85 & 110.25 & -168.10 & -282.63 & 316.19 & -201.66 & -85.65 & -71.12 & 0.758 & 0.524 \\
\hline $50 \mathrm{H}, \mathrm{H}^{\cdots} \mathrm{F}^{-}$ & -57.92 & 109.90 & -167.82 & -277.49 & 306.46 & -196.79 & -78.27 & -75.60 & 0.685 & 0.546 \\
\hline $5 \mathrm{H}, \mathrm{OH} \cdots \mathrm{F}^{-}$ & -60.04 & 109.39 & -169.43 & -297.54 & 340.02 & -211.91 & -102.09 & -67.02 & 0.931 & 0.505 \\
\hline $5 \mathrm{NO}_{2}, \mathrm{H}^{\cdots} \mathrm{F}^{-}$ & -80.40 & 122.66 & -203.06 & -289.61 & 285.50 & -198.94 & -107.73 & -33.07 & 0.826 & 0.362 \\
\hline $5 \mathrm{H}, \mathrm{NO}_{2} \cdots \mathrm{F}^{-}$ & -73.07 & 122.36 & -195.43 & -313.77 & 326.21 & -207.87 & -82.73 & -80.72 & 0.710 & 0.553 \\
\hline $5 \mathrm{CN}, \mathrm{H}^{\cdots \cdots \mathrm{F}^{-}}$ & -77.10 & 125.36 & -202.46 & -292.71 & 287.15 & -196.89 & -102.44 & -41.75 & 0.816 & 0.415 \\
\hline $5 \mathrm{H}, \mathrm{CN} \cdots \mathrm{F}^{-}$ & -70.58 & 125.55 & -196.13 & -316.20 & 326.54 & -206.47 & -85.89 & -75.67 & 0.725 & 0.534 \\
\hline $6 \cdots \mathrm{F}^{-}$ & -52.72 & 113.75 & -166.47 & -242.47 & 231.76 & -155.76 & -86.51 & -28.09 & -114.60 & 0.664 \\
\hline $6 \mathrm{CH}_{3} \cdots \mathrm{F}^{-}$ & -49.46 & 112.25 & -161.71 & -242.98 & 237.01 & -155.74 & -84.74 & -28.81 & 0.656 & 0.365 \\
\hline $60 \mathrm{H} \cdots \mathrm{F}^{-}$ & -53.62 & 113.20 & -166.82 & -249.25 & 243.58 & -161.15 & -90.55 & -27.48 & 0.674 & 0.352 \\
\hline $6 \mathrm{NO}_{2} \cdots \mathrm{F}^{-}$ & -61.12 & 120.30 & -181.42 & -270.50 & 254.16 & -165.07 & -91.23 & -31.10 & 0.698 & 0.380 \\
\hline $6 \mathrm{CN} \cdots \mathrm{F}^{-}$ & -59.50 & 122.63 & -182.13 & -266.89 & 248.02 & -163.25 & -90.69 & -29.39 & 0.690 & 0.368 \\
\hline $7 \cdots \mathrm{F}^{-}$ & -36.46 & 114.01 & -150.47 & -202.18 & 160.13 & -108.42 & -68.29 & - & - & 0.710 \\
\hline $8 \cdots \mathrm{F}^{-}$ & -31.81 & 115.79 & -147.60 & -200.28 & 156.62 & -103.94 & -64.88 & - & - & 0.695 \\
\hline $9 \cdots \mathrm{F}^{-}$ & -49.23 & 106.69 & -155.92 & -201.34 & 163.10 & -117.69 & -71.64 & - & - & 0.692 \\
\hline $10 \cdots \mathrm{F}^{-}$ & -35.17 & 112.81 & -147.98 & -192.88 & 143.67 & -98.77 & -59.84 & - & - & 0.654 \\
\hline
\end{tabular}

${ }^{[a]} \Delta E_{\text {int }}=\Delta V_{\text {elstat }}+\Delta E_{\text {Pauli }}+\Delta E_{\text {oi }} ;$ [b] Values in parentheses correspond to the percentage of each stabilizing contribution $\left(\Delta V_{\text {elstat }}+\Delta E_{o i}=100 \%\right)$.

(1-10) $\cdots \mathrm{F}^{-}$shows, as a whole, similar values (Table 2). Exceptionally, the values of the $\Delta E_{\text {des }}$ parameter in the compounds $\mathbf{9} \cdots \mathrm{F}^{-}$and, chiefly, $\mathbf{1} \cdots \mathrm{F}^{-}$are lower than in the structures (2-8 and 10) $\cdots \mathrm{F}^{-}$. Thus, if consider the interaction energy about the influence of the solvent environment, $\Delta E_{\text {int+des, }}$ the receptors 9 and $\mathbf{1}$ are the $5^{\text {th }}$ and $2^{\text {nd }}$ best compounds to recognize the anion $\mathrm{F}^{-}$, respectively.

The topological analysis of the electron density realized through of the QTAIM method shows the existence of bond critical points (BCPs) between the receptors (1-10) and the anion $\mathrm{F}^{-}$, which point to bonding interactions. ${ }^{39,40}$ The main molecular graphs have been organized in the Figure 3 , while similar representations have been put in the Figure S3. The ratio between the kinetic energy density, $G_{b}$, and the potential energy density, $V_{b},-G_{b} / V_{b}$, and the electron density, $\rho_{b}$, in the main BCPs of the complexes $(\mathbf{1 - 1 0}) \cdots \mathrm{F}^{-}$are organized in the Table S2. To complexes $(\mathbf{1}-\mathbf{1 0}) \cdots \mathrm{F}^{-}$is possible to note BCPs related to $\mathrm{B} \cdots \mathrm{F}^{-}, \mathrm{Te} \cdots \cdot \mathrm{F}^{-}$and $\mathrm{Sb} \cdots \mathrm{F}^{-}$interactions with values between 0.5 and 1.0 of $-G_{b} / V_{b}$. It indicates that the $B \cdots F^{-}, T e \cdots F^{-}$ and $\mathrm{Sb} \cdots \mathrm{F}^{-}$bonds are partially covalent. ${ }^{54}$ Furthermore, there are $\mathrm{C}-\mathrm{H} \cdots \cdot \mathrm{F}^{-}$and $\mathrm{C} \cdots \cdot \mathrm{F}^{-}$interactions with values of $-\mathrm{G}_{\mathrm{b}} / \mathrm{V}_{\mathrm{b}}$ larger than 1.0. These data show that the $\mathrm{C}-\mathrm{H} \cdots \cdot \mathrm{F}^{-}$and $\mathrm{C} \cdots \cdot \mathrm{F}^{-}$bonds are mostly non-covalent. ${ }^{54}$

For the molecules (4-6) $\cdots \cdot \mathrm{F}^{-}$, there are two bonds between 


\section{ARTICLE}

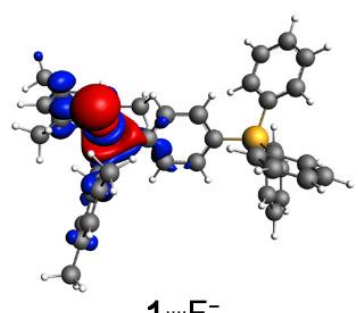

$1 \cdots \mathrm{F}^{-}$

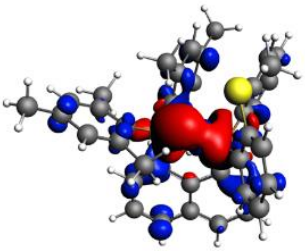

$5 \cdots \cdot F^{-}$

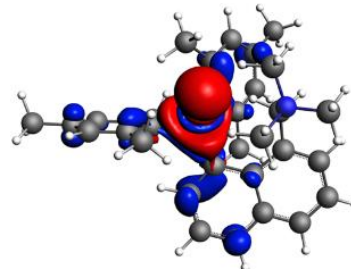

$2 \cdots \mathrm{F}^{-}$

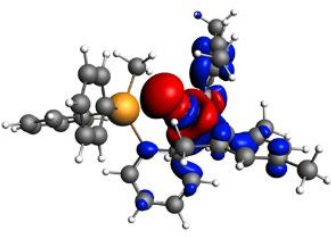

$6 \cdots \mathrm{F}^{-}$

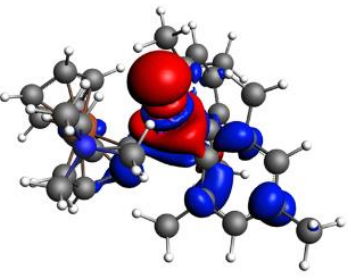

$3 \cdots \mathrm{F}^{-}$

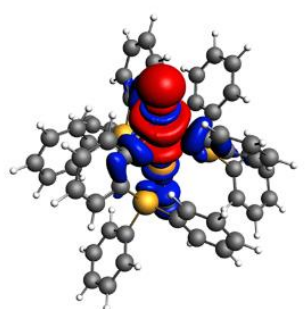

$7 \cdots \mathrm{F}^{-}$

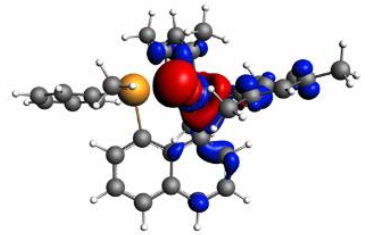

$4 \cdots \mathrm{F}^{-}$

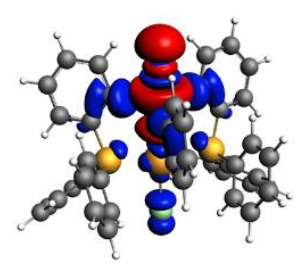

8* $\mathrm{F}^{-}$

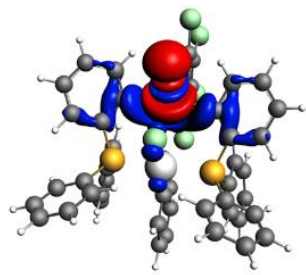

$9 \cdots \mathrm{F}^{-}$

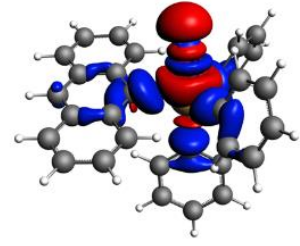

$10 \cdots \mathrm{F}^{-}$

Figure 1. The first density deformation channels, $\Delta \rho_{1}$, for $(\mathbf{1 - 1 0}) \cdots \mathrm{F}^{-}$. Red and blue regions indicate the electronic density outflow and inflow, respectively. The isovalue used to represent these surfaces is 0.001 a. u. Atoms color code: $\mathrm{H}=$ white; $\mathrm{C}=$ gray; $\mathrm{N}=$ blue; $\mathrm{P}=$ gold; $\mathrm{S}=$ yellow; $\mathrm{Cl}=\mathrm{gr}$ een; $\mathrm{Fe}=\mathrm{cooper} ; \mathrm{Pt}=\mathrm{silver} ; \mathrm{Pd}=\mathrm{papaya} ; \mathrm{Sb}$

the atoms present in the receptors structure and the anion $\mathrm{F}^{-}$ with partially covalent character. Together, these two partially covalent chemical bonds have larger $\rho_{b}$ than in the other structures, which have only one partially covalent bond (Table S2). These data are in agreement with the larger values of

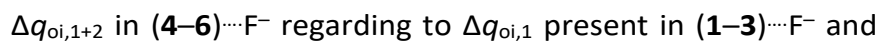
(7-10) $\cdots \mathrm{F}^{-}$(Table 2). Besides, in $4 \cdots \mathrm{F}^{-}$and $6 \cdots \mathrm{F}^{-}$, the $\mathrm{B}-\mathrm{F}^{-}$has larger $\rho_{b}$ (0.111 a.u.) concerning to $\mathrm{Te}-\mathrm{F}^{-}$(0.039 a.u.) and $\mathrm{Sb}-\mathrm{F}^{-}$ (0.039 a.u.) chemical bonds. For the compounds where there is only one $B \cdots F^{-}$interaction, (1-3) $\cdots F^{-}$, it is possible visualize that the values of $\rho_{b}$ in the BCPs of $B-F^{-}(0.129,0.123$ and 0.128 a.u. $)$ are essentially constant. These data show a different tendency regarding to $\Delta q_{\mathrm{oi}, 1}$ parameter. The complex $1 \cdots \mathrm{F}^{-}$shows a larger value of $\Delta q_{\mathrm{oi}, 1}(0.692$ a.u.) concerning to structures ( 2 and $\mathbf{3}) \cdots \cdot \mathrm{F}^{-}$ (0.673 and 0.671 a.u., respectively). For the structures (710) $\cdots \cdot F^{-}$, the partially covalent $\mathrm{Sb} \cdots \mathrm{F}^{-}$interactions show $\rho_{\mathrm{b}}$ values lower than in the $\mathrm{B}^{\cdots} \cdot \mathrm{F}^{-}$interactions in $(\mathbf{1}-\mathbf{3}) \cdots \cdot \mathrm{F}^{-}$. In general, these results not agree with the lower values of $\Delta q_{\mathrm{oi}, 1}$ in (1-3) $\cdots \mathrm{F}^{-}$ (from 0.671 to 0.692 a.u.) compared to (7-10) $\cdots \mathrm{F}^{-}$(from 0.656 to 0.713 a.u.). It can be explained considering that the charge transfer from the anion $\mathrm{F}^{-}$to receptors in the NOCV analysis is also directed to other atoms (than $\mathrm{B}$ or $\mathrm{Sb}$ atoms). The compound $9 \cdots \mathrm{F}^{-}$shows the largest value of $\rho_{b}$ in the $\mathrm{Sb} \cdots \mathrm{F}^{-} \mathrm{BCP}$ (0.103 a.u.), while the complexes $7 \cdots \mathrm{F}^{-}, \mathbf{8} \cdots \mathrm{F}^{-}$and $10 \cdots \mathrm{F}^{-}$have $\mathrm{Sb}-$ $\mathrm{F}^{-}$bonds with similar values of $\rho_{\mathrm{b}}(0.091,0.087$ and 0.086 a.u., respectively). Complementary, the structures $(\mathbf{7 - 1 0}) \cdots \mathrm{F}^{-}$have ionic $\mathrm{C}-\mathrm{H}^{\mathrm{N}} \cdot \mathrm{F}^{-}$bonds with values of $\rho_{\mathrm{b}}$ from 0.012 to $0.015 \mathrm{a} . \mathrm{u}$.

\subsection{Designing Compounds to Fluoride Recognition}

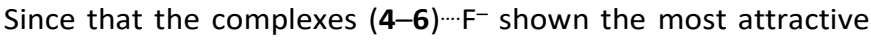
values of the $\Delta E_{\text {int }}$ energy, the receptors 4-6 have been used as base for the design of compounds with larger skill for interact with the $\mathrm{F}^{-}$anion. To modulate the affinity of the receptors 4-6 regarding to anion $\mathrm{F}^{-}$, hydrogen atoms present in the aromatic rings of the molecules $\mathbf{4 - 6}$ have been substituted by electron donor or acceptor groups, such as, $-\mathrm{OH},-\mathrm{CH}_{3},-\mathrm{CN}$ and $-\mathrm{NO}_{2}$ (Scheme 2 and Table 2).

Initially, the presence of the groups $-\mathrm{OH},-\mathrm{CH}_{3},-\mathrm{CN}$ and $\mathrm{NO}_{2}$ in the receptor structure 4 promotes a decrease of the values of the bond length $r\left(B \cdots \cdot F^{-}\right)$, but increase the values of the

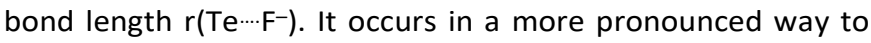
electron acceptor groups $-\mathrm{CN}$ and $-\mathrm{NO}_{2}$ concerning to electron 

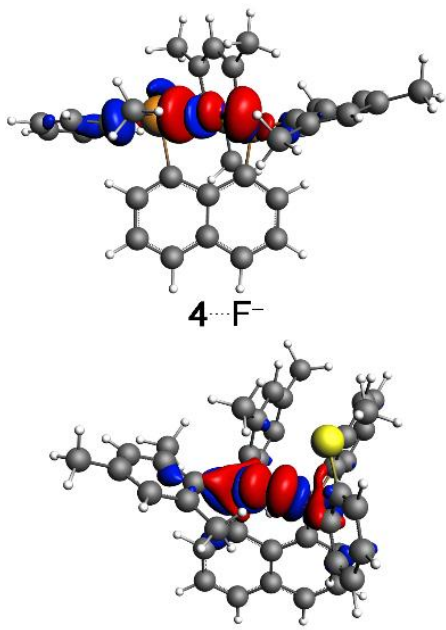

$5 \cdots \mathrm{F}^{-}$

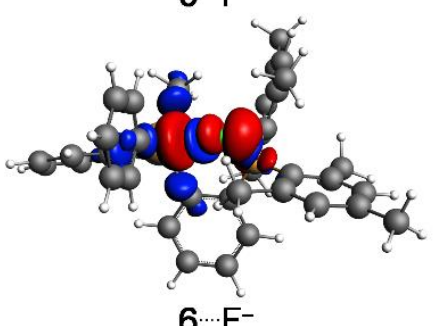

6‥ $\mathrm{F}^{-}$

Figure 2. The second density deformation channels, $\Delta \rho_{2}$, for (4-6) $\cdots \mathrm{F}^{-}$. Red and isove regions indicate the electronic density outflow and inflow, respectively. The white; $\mathrm{C}=$ gray; $\mathrm{S}=$ yellow; $\mathrm{Sb}=$ tangerine; and $\mathrm{Te}=$ orange.

donor groups $-\mathrm{OH}$ and $-\mathrm{CH}_{3}$ (Table 1). The presence of the groups $-\mathrm{OH}$ and $-\mathrm{CH}_{3}$ in the $-\mathrm{R}_{2}$ position of the complex 5 increase the bond length $\mathrm{r}\left(\mathrm{B} \cdots \mathrm{F}^{-}\right)$associated to boron atom in the anthracene derivative ring. On the other hand, the presence of the groups $-\mathrm{CN}$ and $-\mathrm{NO}_{2}$ in the $-\mathrm{R}_{2}$ position of the receptor 5 decrease the bond length $r\left(B \cdots \cdot \mathrm{F}^{-}\right)$associated to boron atom in the anthracene derivative ring. These substitutions in the $-R_{2}$ position promote the opposite trend in the bond length $r\left(B \cdots \mathrm{F}^{-}\right)$ related to another boron atom of the compound $\mathbf{5}$. Overall, the $-\mathrm{H} \rightarrow-\mathrm{OH},-\mathrm{CH}_{3},-\mathrm{CN}$ or $-\mathrm{NO}_{2}$ substitutions in the $-\mathrm{R}_{3}$ group of the receptor 5 promote a decrease of the bonds length $r\left(B \cdots \cdot F^{-}\right)$. Again, the acceptor groups promote more pronounced changes in the values of $\mathrm{r}\left(\mathrm{B} \cdots \mathrm{F}^{-}\right)$. The $-\mathrm{H} \rightarrow-\mathrm{OH},-\mathrm{CH}_{3},-\mathrm{CN}$ or $-\mathrm{NO}_{2}$ substitutions in the receptor 6 promote, in general, a decrease of the bonds lengths $r\left(B \cdots F^{-}\right)$and $r\left(S b \cdots F^{-}\right)$. Exceptionally, there is an increase of: i) $r\left(B \cdots F^{-}\right)$in $6 \cdots F^{-} \rightarrow 6 C^{-} \mathrm{H}_{3} \cdots F^{-}$; and ii) $r\left(S b \cdots F^{-}\right)$ in $6 \cdots \mathrm{F}^{-} \rightarrow 60 \mathrm{H} \cdots \mathrm{F}^{-}$. These data indicate that the electron acceptor groups $-\mathrm{CN}$ and $-\mathrm{NO}_{2}$, preferentially, will favor the $\mathrm{F}^{-}$ recognition.

The EDA analysis shows, firstly, that the interactions between the substituted receptors from 4-6 and the anion $\mathrm{F}^{-}$ are predominantly supported by the $\Delta V_{\text {elstat }}$ term (58-62\%), but also show a relevant contribution of the $\Delta E_{\mathrm{oi}}$ component (38$42 \%)$ to sum of the attractive energy components ( $\Delta V_{\text {elstat }}+$ $\left.\Delta E_{\mathrm{oi}}\right)$. The nature of these chemical bonds are similar to observed in the complexes (4-6)… $\mathrm{F}^{-}$(Table 2).

The presence of the electron donor group $-\mathrm{CH}_{3}$ in the receptor 4 destabilizes the interaction with the anion $\mathrm{F}^{-}$ compared to complex $\mathbf{4} \cdots \mathrm{F}^{-}$(Figure $4 \mathrm{a}$ ). It occurs due to less stabilizing value of the $\Delta V_{\text {elstat }}$ energetic term and more
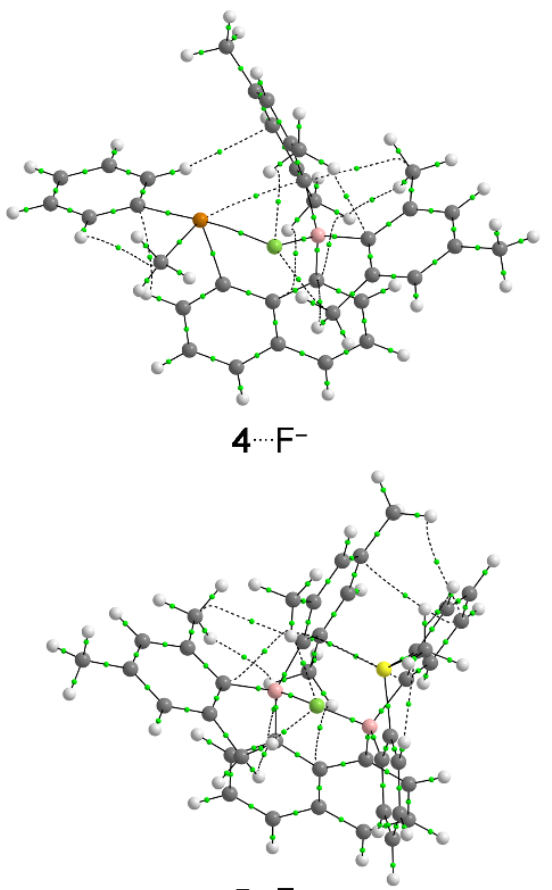

$5 \cdots \cdot \mathrm{F}^{-}$

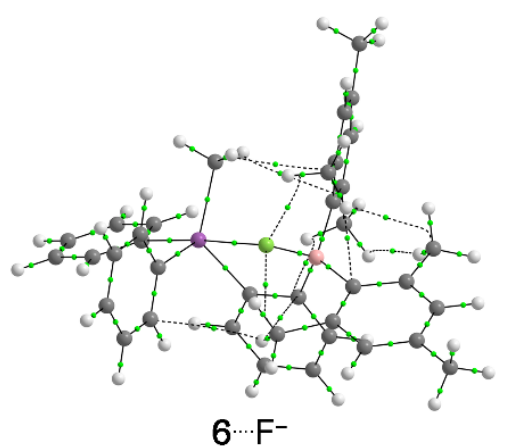

Figure 3. Topological map containing the bond paths (continuous or dashed lines connecting the cores) and bond critical points (small light green points), for the complexes $(4-6) \cdots \mathrm{F}^{-}$. Atoms color code: $\mathrm{H}=$ white; $\mathrm{B}=$ pink; $\mathrm{C}=$ gray; $\mathrm{F}=$ green; $\mathrm{S}$
= yellow; $\mathrm{Sb}=$ purple; and $\mathrm{Te}=$ brown.

repulsive value of the $\Delta E_{\text {Pauli }}$ energy component, despite of the more attractive value of the $\Delta E_{\text {oi }}$ energy in the $4 \mathrm{CH}_{3} \cdots \mathrm{F}^{-}$ interaction. The groups $-\mathrm{OH},-\mathrm{NO}_{2}$ or $-\mathrm{CN}$ in the structure 4 favor the interaction with the anion $\mathrm{F}^{-}$regarding to compound 4 $\cdots \mathrm{F}^{-}$. It can be explained from the more attractive values of the $\Delta V_{\text {elstat }}$ and $\Delta E_{\text {oi }}$ energies, despite of the more repulsive values of the $\Delta E_{\text {Pauli }}$ component in the $\mathbf{4 O H} \cdots \mathrm{F}^{-}, \mathbf{4} \mathrm{NO}_{2} \cdots \mathrm{F}^{-}$and $\mathbf{4} \mathrm{CN} \cdots \mathrm{F}^{-}$ bonds compared to $4 \cdots \cdot \mathrm{F}^{-}$interaction (Figure 4 ). Overall, the best compounds designed from the receptor 4 to interact with the anion $\mathrm{F}^{-}$are the structures $\mathbf{4} \mathbf{N O}_{2}$ and $\mathbf{4} \mathbf{C N}$.

The presence of the electron donor groups $-\mathrm{CH}_{3}$ and $-\mathrm{OH}$ in the structure $\mathbf{5}$ destabilize the $\mathbf{5 C H}_{\mathbf{3}} \cdots \mathrm{F}^{-}$and $\mathbf{5 0 H} \cdots \mathrm{F}^{-}$ interactions regarding to $5 \cdots \mathrm{F}^{-}$bond (Figure $5 \mathrm{a}$ ). When the $-\mathrm{H}$ $\rightarrow-\mathrm{CH}_{3}$ or $-\mathrm{OH}$ substitutions occur in the $-\mathrm{R}_{2}$ position, $\mathbf{5 C H}_{3}, \mathbf{H} \cdots \mathrm{F}^{-}$and $\mathbf{5 O H}, \mathbf{H} \cdots \mathrm{F}^{-}$, respectively, it is because of the less stabilizing values of the $\Delta V_{\text {elstat }}$ term and more repulsive values of the $\Delta E_{\text {Pauli }}$ component, despite of the more attractive values of the $\Delta E_{\text {oi }}$ energy in the $\mathbf{5 C H}_{3}, \mathbf{H} \cdots \mathrm{F}^{-}$and $\mathbf{5 O H}, \mathbf{H} \cdots \cdot \mathrm{F}^{-}$interactions than in the $5 \cdots \mathrm{F}^{-}$bond (Figure $4 \mathrm{~b}$ ). However, when the $-\mathrm{H} \rightarrow-$ $\mathrm{CH}_{3}$ or $-\mathrm{OH}$ substitutions occur in the $-\mathrm{R}_{3}$ position, $5 \mathrm{H}, \mathrm{CH}_{3} \cdots \mathrm{F}^{-}$ 


\section{ARTICLE}

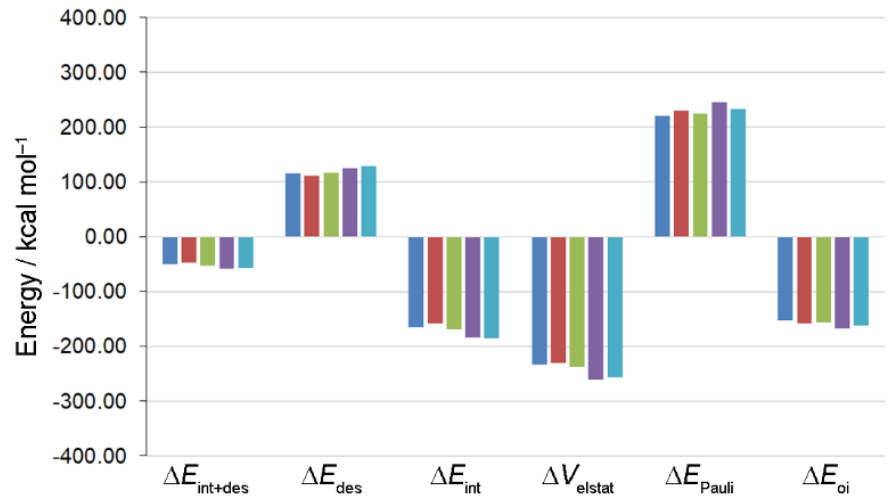

(a)

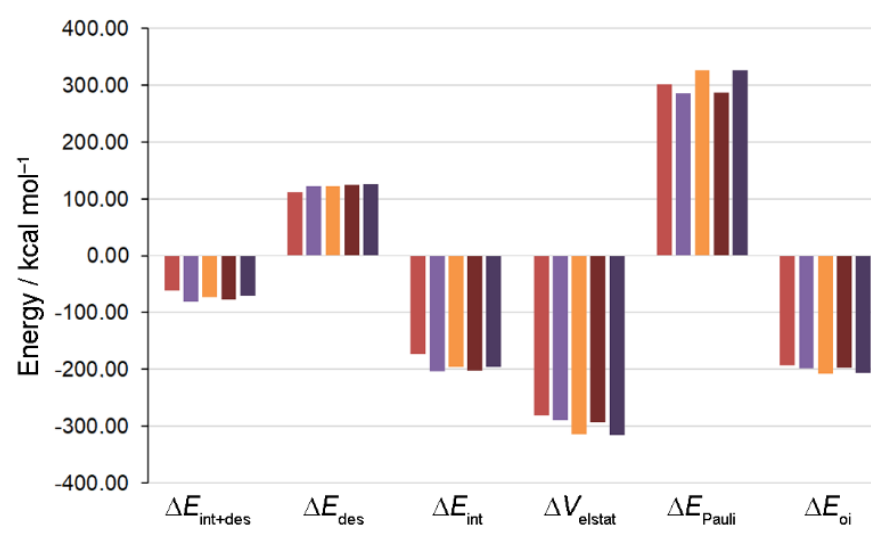

(c)

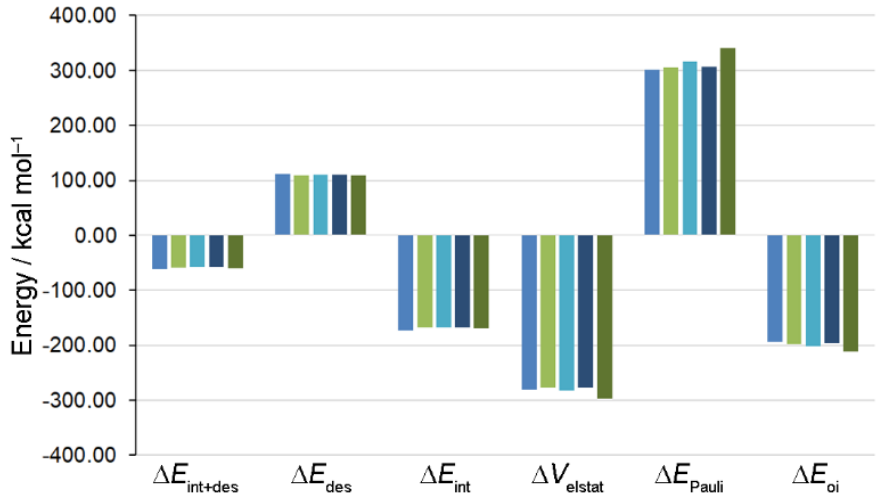

(b)

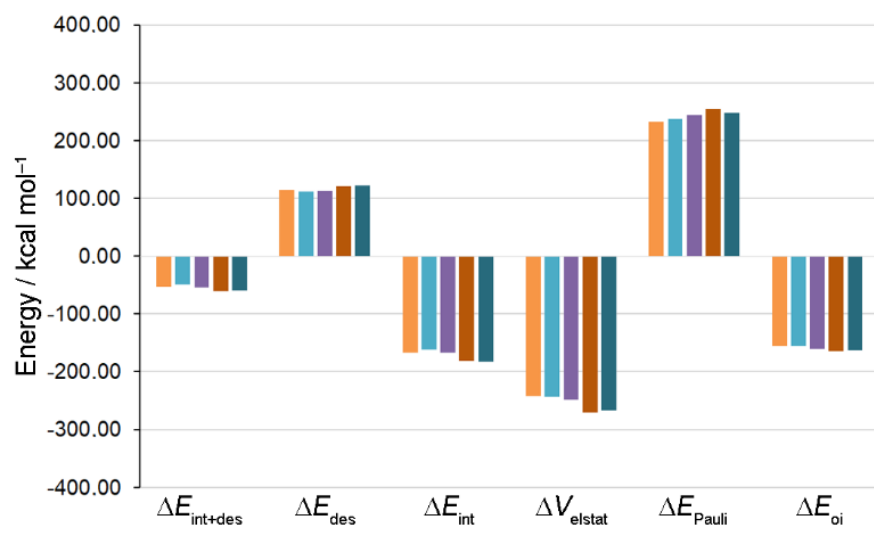

(d)

Figure 4. EDA results and desolvation energy to complexes: (a) $4 \cdots \mathrm{F}^{-}$(blue bar), $4 \mathrm{CH}_{3} \cdots \mathrm{F}^{-}$(red bar), $40 \mathrm{H}^{-\cdots} \mathrm{F}^{-}$(green bar), $4 \mathrm{NO}_{2} \cdots \mathrm{F}^{-}$(purple bar) and $4 \mathrm{CN}^{-\cdots \cdots \mathrm{F}^{-}}$(light blue bar); (b) $5 \cdots \mathrm{F}^{-}$

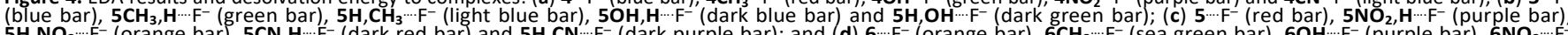
(brown bar) and $6 \mathrm{NO}_{2} \cdots \mathrm{F}^{-}$(orange bar), $5 \mathrm{CN}, \mathrm{H}^{-}$(dark turquoise bar).

and $\mathbf{5 H}, \mathbf{O H} \cdots \mathrm{F}^{-}$, respectively, it is due the more repulsive values of the $\Delta E_{\text {Pauli }}$ term, despite of the more attractive values of the $\Delta V_{\text {elstat }}$ and $\Delta E_{\text {oi }}$ energetic components in the $5 \mathrm{H}, \mathrm{CH}_{3} \cdots \mathrm{F}^{-}$and $\mathbf{5 H}, \mathbf{O H} \cdots \mathrm{F}^{-}$bonds in relation to $\mathbf{5} \cdots \mathrm{F}^{-}$interaction.

Electron acceptor groups $-\mathrm{NO}_{2}$ and $-\mathrm{CN}$ in the structure 5 promote a more favorable interaction with the anion $\mathrm{F}^{-}$(Figure 4c). It can be explained from the more attractive values of the $\Delta V_{\text {elstat }}$ and $\Delta E_{\text {oi }}$ energetic terms and less repulsive values of the $\Delta E_{\text {Pauli }}$ energy in the $\mathbf{5} \mathbf{N O}_{2}, \mathbf{H}^{\prime} \cdots \mathrm{F}^{-}$and $\mathbf{5} \mathbf{C N}, \mathbf{H}^{\prime} \cdots \mathrm{F}^{-}$interactions ($\mathrm{NO}_{2}$ and $-\mathrm{CN}$ acceptor groups present in the $-\mathrm{R}_{2}$ position of the structure 5 ) concerning to $5 \cdots \mathrm{F}^{-}$bond (Figure $4 \mathrm{c}$ ). In addition, it appears from the more favorable values of the $\Delta V_{\text {elstat }}$ and $\Delta E_{\mathrm{oi}}$ energy components, despite of the more repulsive values of the $\Delta E_{\text {Pauli }}$ term in the $\mathbf{5 H}, \mathbf{N O}_{2} \cdots \mathrm{F}^{-}$and $\mathbf{5} \mathbf{H}, \mathbf{C N} \cdots \mathrm{F}^{-}$bonds $\left(-\mathrm{NO}_{2}\right.$ and $\mathrm{CN}$ acceptor groups present in the $-\mathrm{R}_{3}$ position of the structure 5) regarding to $\mathbf{5} \cdots \mathrm{F}^{-}$interaction. As a whole, the receptors designed from the compound $\mathbf{5}$ that best interact with the $\mathrm{F}^{-}$ anion are the molecules $\mathbf{5} \mathbf{N O}_{2}, \mathbf{H}$ and $\mathbf{5 C N}, \mathbf{H}$.
The $-\mathrm{H} \rightarrow-\mathrm{CH}_{3}$ substitutions in the structure 6 destabilize the interaction with the anion $\mathrm{F}^{-}$due to more repulsive value of the $\Delta E_{\text {Pauli }}$ energy in the $6 \mathrm{CH}_{3} \cdots \mathrm{F}^{-}$bond concerning to $6 \cdots \mathrm{F}^{-}$ interaction (Figure $4 \mathrm{~d}$ ). There are similar values of the $\Delta V_{\text {elstat }}$ and $\Delta E_{\text {oi }}$ components in the $6 \mathrm{CH}_{3} \cdots \mathrm{F}^{-}$and $6 \cdots \mathrm{F}^{-}$bonds. The $60 \mathrm{H} \cdots \mathrm{F}^{-}$interaction shows a close value of the $\Delta E_{\text {int }}$ energy compared to $6 \cdots \mathrm{F}^{-}$bond. It is because the more favorable values of the $\Delta V_{\text {elstat }}$ and $\Delta E_{\text {oi }}$ energies are counterbalanced by the more repulsive value of the $\Delta E_{\text {Pauli }}$ term in the $60 \mathrm{H} \cdots \mathrm{F}^{-}$bond regarding to $6 \cdots \mathrm{F}^{-}$interaction. The $6 \mathrm{NO}_{2} \cdots \mathrm{F}^{-}$and $\mathbf{6 C N} \cdots \mathrm{F}^{-}$bonds are more favorable than the $6 \cdots \mathrm{F}^{-}$interaction. It is due to more attractive values of the $\Delta V_{\text {elstat }}$ and $\Delta E_{\mathrm{oi}}$ terms, in spite of the more repulsive value of the $\Delta E_{\text {Pauli }}$ component in the $6 \mathrm{NO}_{2} \cdots \mathrm{F}^{-}$ and $\mathbf{6 C N} \cdots \mathrm{F}^{-}$interactions compared to $6 \cdots \mathrm{F}^{-}$bond.

The NOCV methodology also has been applied to complexes (4-6) $\cdots \mathrm{F}^{-}$after the $-\mathrm{H} \rightarrow-\mathrm{OH},-\mathrm{CH}_{3},-\mathrm{CN}$ or $-\mathrm{NO}_{2}$ substitutions. The most relevant density deformation isosurfaces to these structures are shown in the Figures S1 and S2 due to similarity with the isosurfaces related to complexes $(4-6) \cdots \cdot F^{-}$. Thus, the $F^{-}$ 
recognition in the substituted complexes also is supported by $\sigma$-bond interactions. The substituted compounds show more favorable values of the $\Delta E_{\text {oi }}$ component compared to nonsubstituted molecules (4-6) $\cdots \mathrm{F}^{-}$. In general, it is because of the sum of the more attractive orbital interactions energy and more significant charge transfer values in the first two density deformation isosurfaces $\left(\Delta E_{\mathrm{oi}, 1}\right.$ and $\Delta E_{\mathrm{oi}, 2}$, and $\Delta q_{\mathrm{oi}, 1}$ and $\Delta q_{\mathrm{oi}, 2}$, respectively) present in the substituted complexes than in the

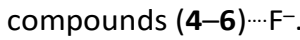

Furthermore, the change in the values of the $\Delta E_{\text {des }}$ term in the complexes (4-6) $\cdots \mathrm{F}^{-}$after the $-\mathrm{H} \rightarrow-\mathrm{OH},-\mathrm{CH}_{3},-\mathrm{CN}$ or $-\mathrm{NO}_{2}$ substitutions shows an opposite trend regarding to $\Delta E_{\text {int }}$ energy (Table 2). However, the desolvation penalty summed to $\Delta E_{\text {int }}$ energy, $\Delta E_{\text {int+des, }}$ not promotes a change in the tendency concerning to $\Delta E_{\text {int }}$ component.

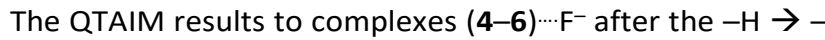
$\mathrm{OH},-\mathrm{CH}_{3},-\mathrm{CN}$ or $-\mathrm{NO}_{2}$ substitutions are organized in the

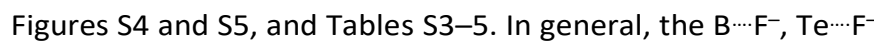
and $\mathrm{Sb} \cdots \mathrm{F}^{-}$interactions show values of $-\mathrm{G}_{\mathrm{b}} / \mathrm{V}_{\mathrm{b}}$ between 0.5 and 1.0. It indicates that these bonds have a partially covalent character. ${ }^{54}$ Exceptionally, the $\mathrm{Te} \cdots \mathrm{F}^{-}$bonds in the complexes $\mathbf{4} \mathrm{NO}_{2} \cdots \mathrm{F}^{-}$and $\mathbf{4} \mathbf{C N} \cdots \mathrm{F}^{-}$have values of $-\mathrm{G}_{\mathrm{b}} / \mathrm{V}_{\mathrm{b}}$ larger than 1.0. So, these chemical bonds show a predominantly non-covalent nature. ${ }^{54}$ Furthermore, there are $\mathrm{C}-\mathrm{H}^{\prime} \cdots \mathrm{F}^{-}, \mathrm{C} \cdots \mathrm{F}^{-}$and $\mathrm{S} \cdots \mathrm{F}^{-}$ interactions with values of $-G_{b} / V_{b}$ larger than 1.0. Thus, these bonds also appear with a chiefly non-covalent character. ${ }^{54}$

Overall, there are not relevant changes in the values of $\rho_{b}$ in

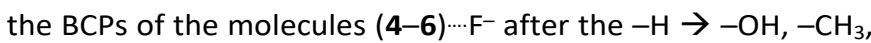
$-\mathrm{CN}$ or $-\mathrm{NO}_{2}$ substitutions. However, there are some interesting exceptions. The presence of acceptor groups $-\mathrm{CN}$ or $-\mathrm{NO}_{2}$ in the compound 4 decrease the values of $\rho_{b}$ in the BCPs of the Te $\cdots \mathrm{F}^{-}$ bonds, and increase the values of $\rho_{b}$ in the BCPs of the B... $F^{-}$ interactions. The presence of the donor group $-\mathrm{OH}$ in the $-\mathrm{R}_{2}$ position of the structure 5 decrease the value of $\rho_{b}$ in the BCP of the $B \cdots \mathrm{F}^{-}$interaction associated to boron atom in the anthracene derivate ring. On the other hand, this substitution increase the value of $\rho_{b}$ in the BCP of the another $B \cdots \cdot F^{-}$bond. The presence of the acceptor groups $-\mathrm{CN}$ or $-\mathrm{NO}_{2}$ in the $-\mathrm{R}_{2}$ position of the structure $\mathbf{5}$ promote the opposite trend in the $\mathrm{B} \cdots \mathrm{F}^{-}$interactions concerning to trend visualized from the presence of the donor group - $\mathrm{OH}$. Lastly, the presence of the acceptor group $-\mathrm{NO}_{2}$ in the $-\mathrm{R}_{3}$ position of the molecule 5 increase the value of $\rho_{b}$ in the BCP of the $B \cdots F^{-}$interaction, nonrelated to anthracene derivative ring. These results indicate that donor $(-\mathrm{OH})$ and, chiefly, acceptor groups $\left(-\mathrm{CN}\right.$ and $\left.-\mathrm{NO}_{2}\right)$ in the receptors structure support a more asymmetrical distribution of the electrons density between the atoms of the receptors structure and the anion $\mathrm{F}^{-}$, in agreement with the EDA-NOCV data.

\section{Conclusions}

Therefore, the $(\mathbf{1}-\mathbf{1 0}) \cdots \cdot \mathrm{F}^{-}$interactions have an electrostatic predominantly energy, but with a relevantly contribution of the orbital interactions energy. The receptor $\cdots \cdot \mathrm{F}^{-}$bonds with the most favorable interaction energy were decomposed in: $\Delta V_{\text {elstat }}$ $(59-61 \%)+\Delta E_{\mathrm{oi}}(39-41 \%)$. The receptors that directly interact with the ion $\mathrm{F}^{-}$from: i) two $\mathrm{B}$ atoms (5); ii) one $\mathrm{B}$ atom and one $\mathrm{Sb}$ atom (6); and iii) one B atom and one Te atom (4), appear as one of the best structures to recognize the fluoride anion. The receptors 4-6 preferentially recognize the anion $\mathrm{F}^{-}$concerning to compounds 1-3 (one $B$ atom directly interact with the anion $\mathrm{F}^{-}$) and 7-10 (one $\mathrm{Sb}$ atom directly interact with the anion $\mathrm{F}^{-}$) due to more attractive electrostatic and orbital interactions, despite of the larger Pauli repulsion energy in the (4-6) $\cdots \cdot \mathrm{F}^{-}$ bonds regarding to $(\mathbf{1}-\mathbf{3}) \cdots \mathrm{F}^{-}$and $(\mathbf{7}-\mathbf{1 0}) \cdots \mathrm{F}^{-}$interactions. Importantly, the NOCV methodology shows that the main orbital interactions behind the $\mathrm{F}^{-}$recognition are $\sigma$ bonds established between the receptors $\mathbf{1 - 1 0}$ and the anion $\mathrm{F}^{-}$. Thus, the positively charged compounds that interact with the fluoride anion from, mainly, two partially covalent chemical bonds (involving at least one B atom) in sterically-confined binding sites appear, as a whole, as the best candidates to promote the recognition of the ion. As exception, the receptors 1 and 9 with very open binding sites also are potential structures to recognize the anion $\mathrm{F}^{-}$due to lower values of the desolvation energy in the complexes $\mathbf{1} \cdots \mathrm{F}^{-}$and $\mathbf{9} \cdots \mathrm{F}^{-}$regarding to compounds (2-8 and 10) $\cdots \mathrm{F}^{-}$. In general, electron donor groups as, for example, $-\mathrm{CH}_{3}$ and $-\mathrm{OH}$ in the structure of the receptors 4-6 decrease the skill these structures to recognize the anion $\mathrm{F}^{-}$. It occurs due these changes decrease the favorable electrostatic energy and an increase the Pauli repulsion energy in the (4-6) $\cdots \mathrm{F}^{-}$bonds. Exceptionally, the anion $\mathrm{F}^{-}$is: i) preferably recognized by the structure $\mathbf{4 O H}$; and ii) similarly recognized by the receptor $60 \mathrm{H}$, regarding to compound 6 . It is due to more attractive electrostatic and orbital interactions energy that overcomes $\left(40 \mathrm{OH} \cdots \mathrm{F}^{-}\right.$regarding to $\left.4 \cdots \mathrm{F}^{-}\right)$or counterbalance $\left(60 \mathrm{H} \cdots \mathrm{F}^{-}\right.$concerning to $\left.6 \cdots \mathrm{F}^{-}\right)$the Pauli repulsion energy. Importantly, the presence of electron acceptor groups, such as, $-\mathrm{CN}$ and $-\mathrm{NO}_{2}$ in the receptors that preferably interacted with the anion $\mathrm{F}^{-}, \mathbf{4 - 6}$, improve the skill these structures for the $\mathrm{F}^{-}$recognition using more favorable electrostatic and orbital interactions. Thus, the present investigation elucidated the main features of the experimentally developed receptors to recognize the fluoride anion and, chiefly, pointed principles to improve the anionic recognition of $\mathrm{F}^{-}$.

\section{Conflicts of Interest}

There are no conflicts to declare.

\section{Author Contributions}

R.P.O., G.F.C. and R.L.T.P. conceptualized this research. R.P.O., M.J.P. and N.H.M. guided the data analysis/interpretation. L.B.P. and K.E.A.B. performed the calculations and the preliminary formal analysis. J.C.-G., C.C. and F.M. reviewed earlier drafts to produce the final version of the paper. R.L.T.P. and G.F.C. also were responsible by funding acquisition and project administration. 


\section{Acknowledgements}

This study was financed in part by the Coordenação de Aperfeiçoamento de Pessoal de Nível Superior - Brasil (CAPES) Finance Code 001. R.L.T.P., N.H.M. and R.P.O. thank grants 2011/07623-8, 2013/08293-7 and 2017/24856-2 São Paulo Research Foundation (FAPESP) for the financial support. G.F.C., N.H.M. and R.L.T.P. thank Conselho Nacional de Desenvolvimento Científico e Tecnológico (CNPq, grants 311963/2017-0, 303581/2018-2 and 313648/2018-2 respectively) for the research fellowship. M.J.P. thanks the Rio Grande do Sul Research Foundation - FAPERGS and CNPq (grants number 306297/2018-3 and 430364/2018-0). J.C.-G. expresses her gratefulness to LabEx CALSIMLAB (public grant ANR-11-LABX-0037-01 constituting a part of the "Investissements d'Avenir" program - reference: ANR-11IDEX-0004-02). C.C. acknowledges support by FONDECYT through project No. 1181121, and also by Centers of Excellence With Basal/Conicyt Financing, Grant FB0807.

\section{References}

1 K. Bowman-James, A. Bianchi and E. García-Espana, Anion Coordination Chemistry, John Wiley \& Sons, Nova Jersey, 2012.

2 H. Zhao, L. A. Leamer and F. P. Gabbaï, Dalton Trans., 2013, 42, 8164-8178.

3 A. O. Ortolan, I. Ostrom, G. F. Caramori, R. L. T. Parreira, E. H. da Silva and F. M. Bickelhaupt, J. Phys. Chem. A, 2018, 122, 3328-3336.

4 A. O. Ortolan, G. F. Caramori, F. M. Bickelhaupt, R. L. T. Parreira, A. Munoz-Castro and T. Kar, Phys. Chem. Chem. Phys., 2017, 19, 24696-24705.

5 J. Aaseth, M. Shimshi, J. L. Gabrilove and G. S. Birketvedt, J. Trace Elem. Exp. Med., 2004, 17, 83-92.

6 R. J. Carton, Fluoride, 2006, 39, 163-172.

7 USEPA Safe Drinking Water Information System, https://www.epa.gov/ground-water-and-drinkingwater/safe-drinking-water-information-system-sdwisfederal-reporting, (accessed June 2021).

8 M. Gerken, J. A. Boatz, A. Kornath, R. Haiges, S. Schneider, T. Schroer and K. O. Christe, J. Fluorine Chem., 2002, 116, 49-58.

9 C. R. Wade, I.-S. Ke and F. P. Gabbaï, Angew. Chem., 2012, 124, 493-496.

10 A. Brugnara, F. Topic, K. Rissanen, A. de la Lande, B. Colassona and O. Reinauda, Chem. Sci., 2014, 5, 3897-3904.

11 L. M. P. Lima, A. Lecointre, J.-F. Morfin, A. de Blas, D. Visvikis, L. J. Charbonnière, C. Platas-Iglesias and R. Tripier, Inorg. Chem., 2011, 50, 12508-12521.

12 R. Tripier, C. Platas-Iglesias, A. Boos, J.-F. Morfin and L. Charbonnière, Eur. J. Inorg. Chem., 2010, 2010, 2735-2745.

13 E. L. Yee, O. A. Gansow and M. J. Weaver, J. Am. Chem. Soc., 1980, 102, 2278-2285.

14 C. R. Wade, T.-P. Lin, R. C. Nelson, E. A. Mader, J. T. Miller and F. P. Gabbai, J. Am. Chem. Soc., 2011, 133, 8948-8955.

15 C. R. Wade, A. E. J. Broomsgrove, S. Aldridge and F. P. Gabba, Chem. Rev., 2010, 110, 3958-3984.

16 F. Jäkle, Chem. Rev., 2010, 110, 3985-4022.

17 D. W. Stephan, Dalton Trans., 2009, 3129-3136.

18 C. Dusemund, K. R. A. S. Sandanayake and S. Shinkai, J. Chem. Soc., Chem. Commun., 1995, 333-334.

19 C. R. Wade and F. P. Gabbaï, Organometallics, 2011, 30, 44794481.

20 G. A. Olah, J. Org. Chem., 2005, 70, 2413-2429.
21 B. Pan and F. P. Gabbaï, J. Am. Chem. Soc., 2014, 136, 95649567.

22 L.-J. Baker, C. E. F. Rickard and M. J. Taylor, Acta Crystallogr Sect. C, 1999, C55, 335-337.

23 I.-S. Ke, J. S. Jones and F. P. Gabbaï, Angew. Chem., Int. Ed., 2014, 53, 2633-2637.

24 M. Hirai and F. P. Gabbaï, Angew. Chem. Int. Ed., 2015, 54, 1205-1209.

25 Y. Kim and F. P. Gabbaï, J. Am. Chem. Soc., 2009, 131, 33633369.

26 A. E. J. Broomsgrove, D. A. Addy, A. Di Paolo, I. R. Morgan, C. Bresner, V. Chislett, I. A. Fallis, A. L. Thompson, D. Vidovic and S. Aldridge, Inorg. Chem., 2010, 49, 157-173.

27 I.-S. Ke, M. Myahkostupov, F. N. Castellano and F. P. Gabbaï, J. Am. Chem. Soc., 2012, 134, 15309-15311.

28 A. D. Becke, Phys. Rev. A, 1988, 38, 3098-3100.

29 J. P. Perdew, Phys. Rev. B, 1986, 33, 8822-8824.

30 S. Grimme, J. Comput. Chem., 2006, 27, 1787-1799.

31 S. Grimme, J. Antony, S. Ehrlich and H. Krieg, J. Chem. Phys. 2010, 132, 154104.

32 S. Grimme, Wiley Interdiscip. Rev. Comput. Mol. Sci., 2011, 1 211-228.

33 E. R. Johnson and A. D. Becke, J. Chem. Phys., 2005, 123, 024101.

34 S. Grimme, S. Ehrlich and L. Goerigk, J. Comput. Chem., 2011 32, 1456-1465

35 F. Weigend and R. Ahlrichs, Phys. Chem. Chem. Phys., 2005, 7 , 3297-3305.

36 J. Tomasi, B. Mennucci and R. Cammi, Chem. Rev., 2005, 105 2999-3094.

37 P. M. W. Gill, B. G. Johnson and J. A. Pople, Chem. Phys. Lett., 1993, 209, 506-512.

38 M. J. Frisch, G. W. Trucks, H. B. Schlegel, G. E. Scuseria, M. A Robb, J. R. Cheeseman, G. Scalmani, V. Barone, G. A Petersson, H. Nakatsuji, X. Li, M. Caricato, A. V. Marenich, J. Bloino, B. G. Janesko, R. Gomperts, B. Mennucci, H. P. Hratchian, J. V. Ortiz, A. F. Izmaylov, J. L. Sonnenberg, D. Williams-Young, F. Ding, F. Lipparini, F. Egidi, J. Goings, B. Peng, A. Petrone, T. Henderson, D. Ranasinghe, V. G. Zakrzewski, J. Gao, N. Rega, G. Zheng, W. Liang, M. Hada, M. Ehara, K. Toyota, R. Fukuda, J. Hasegawa, M. Ishida, T. Nakajima, Y. Honda, O. Kitao, H. Nakai, T. Vreven, K. Throssell, J. A. Montgomery Jr., J. E. Peralta, F. Ogliaro, M. J. Bearpark, J. J. Heyd, E. N. Brothers, K. N. Kudin, V. N. Staroverov, T. A. Keith, R. Kobayashi, J. Normand, K. Raghavachari, A. P. Rendell, J. C. Burant, S. S. Iyengar, J. Tomasi, M. Cossi, J. M. Millam, M. Klene, C. Adamo, R. Cammi, J. W. Ochterski, R. L. Martin, K. Morokuma, O. Farkas, J. B. Foresman and D. J. Fox, GAUSSIAN 16 (Revision A.03), Gaussian Inc., Wallingford, CT, 2016

39 R. F. W. Bader, Atoms and Molecules - A Quantum Theory, Clarendon Press Oxford, New York, 1994

40 G. F. Caramori, R. L. T. Parreira and A. M. C. Ferreira, J. Quantum Chem., 2012, 112, 625-646.

41 T. A. Keith, AIMAll, Revision 17.01.25, 2017, TK Gristmill Software, Overland Park KS, USA.

42 F. M. Bickelhaupt and E. J. Baerends, in Reviews in Computational Chemistry, ed. K. B. Lipkowitz and D. B. Boyd, 2000, DOI: 10.1002/9780470125922.ch1.Bader625

43 M. Mitoraj and A. Michalak, J. Mol. Model., 2007, 13, 347355.

44 M. P. Mitoraj, A. Michalak and T. Ziegler, J. Chem. Theory Comput., 2009, 5, 962-975.

45 D. G. Fedorov and K. Kitaura, J. Phys. Chem. A, 2012, 116, 704719.

46 Y. Mao, M. Loipersberger, K. J. Kron, J. S. Derrick, C. J. Chang, S. M. Sharada and M. Head-Gordon, Chem. Sci., 2021, 12 1398-1414. 
47 E. van Lenthe and E. J. Baerends, J. Comput. Chem., 2003, 24, 1142-1156.

48 M. Swart, M. Solà and F. M. Bickelhaupt, J. Chem. Theory Comput., 2010, 6, 10.

49 E. van Lenthe, E. J. Baerends and J. G. Snijders, J. Chem. Phys., 1993, 99, 4597.

50 M. Franchini, P. H. T. Philipsen and L. Visscher, J. Comput. Chem., 2013, 34, 1819-1827.

51 G. te Velde, F. M. Bickelhaupt, E. J. Baerends, C. Fonseca Guerra, S. J. A. van Gisbergen, J. G. Snijders and T. Ziegler, J. Comput. Chem., 2001, 22, 931-967.

52 C. F. Guerra, J. G. Snijders, G. te Velde and E. J. Baerends, Theor. Chem. Acc., 1998, 99, 391-403.

53 E. J. Baerends, T. Ziegler, A. J. Atkins, J. Autschbach, O. Baseggio, D. Bashford, A. Bérces, F. M. Bickelhaupt, C. Bo, P. M. Boerrigter, L. Cavallo, C. Daul, D. P. Chong, D. V. Chulhai, L. Deng, R. M. Dickson, J. M. Dieterich, D. E. Ellis, M. van Faassen, L. Fan, T. H. Fischer, A. Förster, C. Fonseca Guerra, M. Franchini, A. Ghysels, A. Giammona, S. J. A. van Gisbergen, A. Goez, A. W. Götz, J. A. Groeneveld, O. V. Gritsenko, M. Grüning, S. Gusarov, F. E. Harris, P. van den Hoek, Z. Hu, C. R. Jacob, H. Jacobsen, L. Jensen, L. Joubert, J. W. Kaminski, G. van Kessel, C. König, F. Kootstra, A. Kovalenko, M. V. Krykunov, E. van Lenthe, D. A. McCormack, A. Michalak, M. Mitoraj, S. M. Morton, J. Neugebauer, V. P. Nicu, L. Noodleman, V. P. Osinga, S. Patchkovskii, M. Pavanello, C. A. Peeples, P. H. T. Philipsen, D. Post, C. C. Pye, H. Ramanantoanina, P. Ramos, W. Ravenek, M. Reimann, J. I. Rodríguez, P. Ros, R. Rüger, P. R. T. Schipper, D. Schlüns, H. van Schoot, G. Schreckenbach, J. S. Seldenthuis, M. Seth, J. G. Snijders, M. Solà, M. Stener, M. Swart, D. Swerhone, V. Tognetti, G. te Velde, P. Vernooijs, L. Versluis, L. Visscher, O. Visser, F. Wang, T. A. Wesolowski, E. M. van Wezenbeek, G. Wiesenekker, S. K. Wolff, T. K. Woo and A. L. Yakovlev, ADF 2020, SCM, Theoretical Chemistry, Vrije Universiteit, Amsterdam, The Netherlands, http://www.scm.com.

54 D. Cremer and E. Kraka, Angew. Chem. Int. Ed. Engl., 1984, 23 627-628. 